\title{
Ultrastructural Characterization of the Buccal Cavity Floor of the Striped Red Mullet fish Mullus Surmuletus (Linnaeus, 1758)
}

\author{
Mohamed M.A. Abumandour, ${ }^{1}$ Neveen E.R. El-Bakary ${ }^{2}$ \\ 'Department of Anatomy and Embryology, Faculty of Veterinary Medicine, Alexandria University \\ ${ }^{2}$ Department of Zoology, Faculty of Science, Damietta University, Egypt
}

Disclose and conflicts of interest: none to be declared by all authors

\begin{abstract}
Introduction: The present investigation focused on scanning electron microscopic (SEM) characteristics of the buccal cavity floor of the striped red mullet fish Mullus surmuletus. It consisted of the upper lip, dentaries, in addition to three regions; velum region, pre-lingual region, and the lingual region. The two dentaries regions contained three main structures; the papillary-like teeth, surrounded by a large number of taste buds, in addition to a few numbers of the large-sized taste pores. The high SEM magnification showed that, the papillary-like teeth were surrounded by the circular crypts on its base, with the proximal end blunted curved and free from epithelium cover. The two dentaries regions were separated from each other by a narrow slightly elevated median region. This region, under SEM high magnifications, presents numerous numbers of filiformlike papillary structures. The dorsal lingual surface contained numerous lingual tubercle and taste buds. In conclusion, the current results describe the adaptations of the buccal cavity floor and its structures with the feeding mechanisms in the striped red mullet fish.
\end{abstract}

Keywords: Buccal cavity floor; Tongue; Dentaries region; Papillary-like teeth; Velum.

\section{Introduction}

The striped red mullet fish belongs to M. surmuletus species and Mullidae family and Mullus genus. The Mullidae family is present in the Mediterranean Sea and it is one of the bottom-feeder fish that depend on worms, crustaceans and other invertebrates in its feeding.

Morphological examination of the different fish species was of great interest to many anatomical researchers ${ }^{1-5}$ especially the anatomical adaptation of the gill with different environmental conditions. ${ }^{6,7}$ The feeding mechanism in all vertebrates is an important factor related to the successful adaptation of vertebrates to their environment. ${ }^{8}$ The buccal cavity played a vital role in seizing, controlling, and selecting food particles and rejecting undesirable food particles ingested by the fish. In the feeding process, the oral cavity played a vital role with the organs within and near it especially the tongue. ${ }^{9}$

In all vertebrates of different lifestyles, the oropharyngeal cavity and its contents, especially the tongue, play an important role in the feeding process and pre-digestion process of the food particles. ${ }^{10,11}$ The morphological studies of the oropharyngeal cavity of fishes had high interest in the last decades. ${ }^{9,12,13}$ The main role of the oral cavity was correlated with the processing of food such as food particle intake, food processing, and swallowing, this main role of the oral cavity being different according to the fish species and related to the surrounding environmental conditions. ${ }^{1,13-20}$

The buccal cavity of fish species was correlated with many vital functions as it was considered the only entrance of the food particles to the digestive system and also the only entrance of the water stream on the gills to extract the oxygen., $3,521,22$ So, this study was performed to understand the important role of the lower jaw of the buccal cavity concerning the food particles and feeding behavior and the surrounding environmental conditions. These data were necessary to understand the adaptation of this fish to its habitat and in developing a new and better method for the breeding of this type of fish in my country. From these points, the current work was focused on the SEM appearance of the lower jaw with its contents (lip, velum and tongue). Then, we comparing the obtained data with those previously published articles.

\section{Materials and Methods}

The current work was performed on ten mature striped red mullet fish M. surmuletus (weighted ranged from $35 \mathrm{gm}$ to $55 \mathrm{gm}$ and the length from $30-35 \mathrm{~cm}$ ). These fishes were collected after their catching from 
the Mediterranean Sea, in Alexandria city, Egypt. Then, they were transported to the anatomical lab within $2 \mathrm{~h}$ in plastic aquariums to perform the scanning electron microscopes studies on the buccal cavity. These fishes must be without oral injuries or any abnormalities. The collected fishes were anesthetized according to the cold method. ${ }^{23}$ The present work was performed according to the guidelines for the care of using animals and the animal welfare and Ethics Committee of the Faculty of Veterinary Medicine, Alexandria University according to the Egyptian's laws, in which adequate measures were taken to minimize the pain or discomfort.

For the SEM studies, the lower jaws of the head of the striped red mullet fish were carefully washed to remove any mucus covering the surface of the buccal cavity by putting in the physiological saline solution according to. ${ }^{24}$ The samples were fixed in formalin $10 \%$. After fixation, the head was opened by dividing the head into an upper and a lower half by cutting horizontally through the mouth. Then, the specimens of the lower jaws of the buccal cavity were extracted immediately after catching. The samples were fixed in a glutaraldehyde $3 \%$ solution at $4{ }^{\circ} \mathrm{C}$ for 24 hours then dehydrated through a graded series of acetone.
After that, the specimens were post-fixed in osmium tetroxide $1 \%$ in a phosphate buffer for 2 hours. The samples were subsequently dehydrated in ascending grades of ethanol followed by critical point drying in carbon dioxide. Then, the samples were coated with gold and examined with JEOL JSM 5300 scanning electron microscope operating at $15 \mathrm{Kv}$, Faculty of Science Alexandria University.

\section{Results}

The symmetrically buccal cavity of the striped red mullet fish M. surmuletus consisted of the floor and roof. The roof of the buccal cavity consisted of the upper jaw, velum and palate. In the Mullus, the absence of teeth in the adult upper jaw is the more characteristic feature. The floor of the buccal cavity consisted of a semicircular lower jaw. The lower jaw consisted of three regions; upper lip, dentaries, velum region, pre-lingual region and the lingual region (Fig. 1).

The two dentaries region of the lower lip contains three main structures; a few numbers of papillary conical-like teeth surrounded by a large number of the taste buds, in addition to the few number of large-sized taste pores (Fig. 1A and 1B). By high magnification, the conical-like papillary teeth penetrated the lower lip
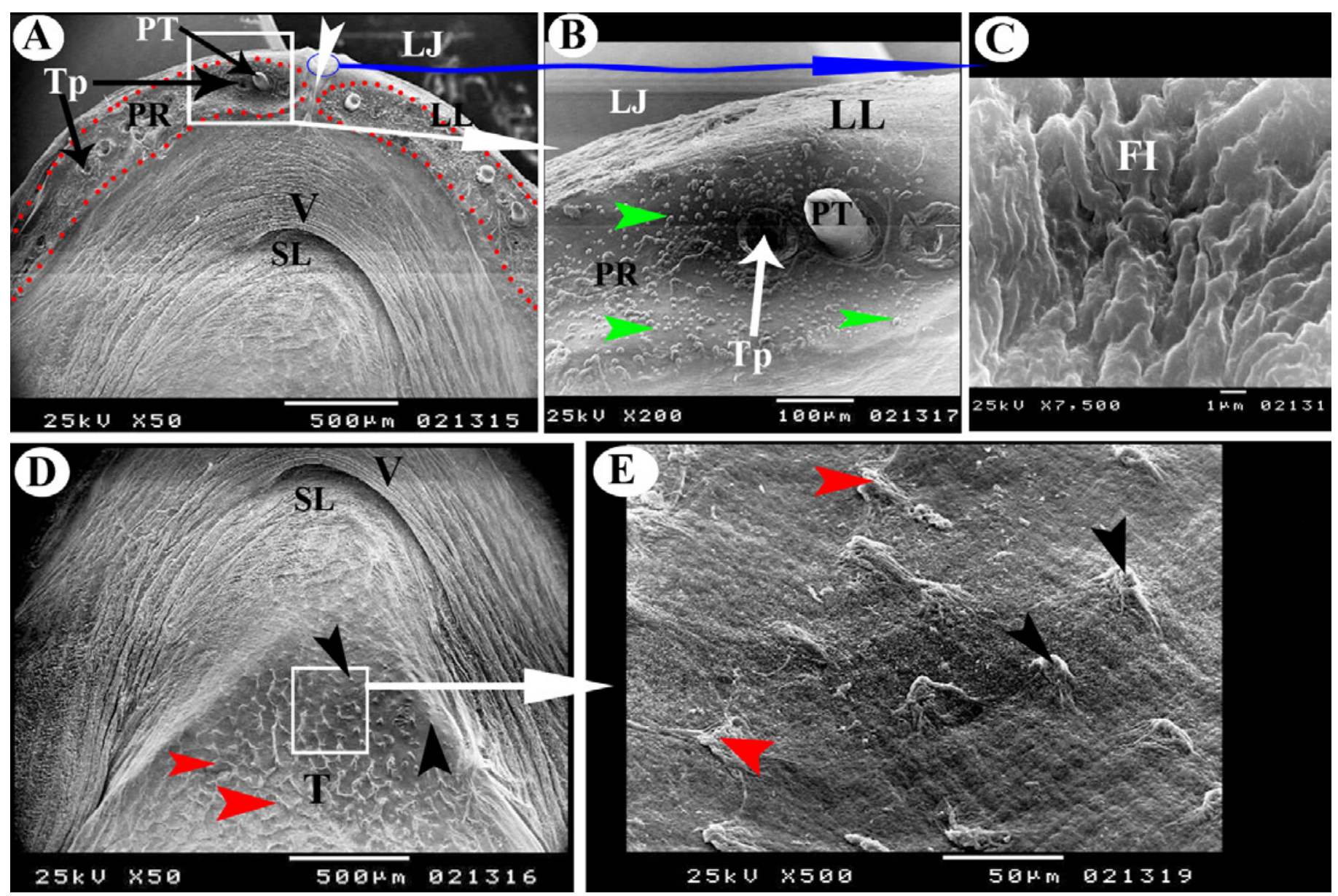

Figure 1. The SEM micrograph on the surface of the lower jaw to show; LJ-Lower jaw; LL- lower lip; PR- Papilliform teeth region; V- Velum; SL- Pre-lingual region; TTongue; Slightly elevated median area of the lower lip (white headarrow); PT- Papilliform teeth; Tp- Taste pores; FI- Filiform-like papillary structures; Taste buds (green headarrow); lingual taste buds (black headarrow); lingual tubercles (red headarrow); the two red dotted area represented the two dentaries region of the lower lip. 
epithelium and were surrounded by the circular crypts on its base, and its proximal end was blunted curved and free from epithelium cover (Fig. 1B). The two dentaries region of the lower lip separated from each other by a narrow slightly elevated median region, this region was continuous caudally with the velum epithelium (Fig. 1A), and with SEM high magnifications there were numerous numbers of the filiform-like papillary structures (Fig. 1C).

The velum region was comprised of a thin fold at the inner border of the lower jaw and was characterized by semicircular striated epithelium surface appearance (Fig. 1A and 1D).

The dorsal surface of the triangular elevated tongue contained numerous lingual tubercle and few numbers of small taste buds on its dorsal surface (Fig. 1D and 1E).

\section{Discussion}

The buccal cavity of fish played an important role in prey capture and food transport and helps in the adaptation of fish to its environment. ${ }^{9}$ From the morphological published data, the surface ultrastructural morphological characteristics of the buccal cavity of carnivorous bottom teleosts were scanty.

There was a correlation between the presence of the papillary-like teeth and the methods of feeding behavior of the different fish species including; seizing, grasping, holding and prevent the escaping of the small food particles from the oral cavity. The teeth on upper and lower jaws were described in several fish species as noted in; the examined fish and ${ }^{1}$ in $\mathrm{R}$. rita and ${ }^{25,26}$ in several catfish species, ${ }^{27}$ in M. cyprinoides, ${ }^{28}$ in Starksiini. Moreover, the recently published SEM articles observed that there are elongated conical spine-shaped teeth on the jaws as noted by:29 in D. clupeoides, ${ }^{30}$ in A. elymus and ${ }^{31}$ in several cardinal fish species, also $^{32}$ in G. morhua observed the presence of simple, pointed teeth on the oral cavity. However, the edentulous jaws were reported in the herbivorous fish as mentioned in; flatfish common solea ${ }^{33}$ and the gilthead seabream ${ }^{4}$ and also these edentulous jaws reported by, ${ }^{25,34,35}$ while the papillary-like teeth was absent completely from the oral cavity in many teleost fishes as mentioned by ${ }^{36}$

The current study with high magnification observed that the papillary-like teeth on the lower lip were surrounded by the circular crypts on its base, similar to that reported by ${ }^{37}$ in his description of the caninelike teeth present in the tongue of the Dicentrarchus labrax.

The lower lip of the examined fish contained a median slightly elevated ridge between the two dentaries region, which characterized by carrying numerous filiform-like papillae with high magnifications, a similar observation noted by ${ }^{1}$ in R. rita, but ${ }^{25}$ not observed this ridge-like structure between dentaries in R. rita.
The gustatory organs or the presence of the taste buds of fishes especially those present on the barbles of the catfish ${ }^{38}$ had more interest however, there is recent interest in the presence of taste buds in and around the oropharyngeal cavity. ${ }^{15,28,39,40}$ The present work observed that there were numerous taste buds and taste pores on the lower lip as mentioned by. ${ }^{15,41,42}$ Our observation suggested that the presence of numerous taste buds on the lips compensated the restricted visibility in the turbid aquatic media in the bottom feeder fish species to help this fish species in the process of the detection of food and choosing the different food types as mentioned previously.,25,43,44 Furthermore, the present investigation reported that there were no taste buds on the velum, this result similar to this observed by ${ }^{18}$ in Salmo gairdneri however, ${ }^{1,45-47}$ observed the presence of taste buds on the velum of S. canicula, cardinal fish, R. Rita and C. mrigala.

Functionally, following the data published by, ${ }^{25}$ the fish species classified according to the taste buds distribution in the oral cavity into three types; the first type, the absence or the rare presence of the taste buds was observed in the carnivores fish species depending on the good eyesight for detection of their prey such as M. telabon and H. nehereus. ${ }^{48}$ In the second type, there were numerous taste buds in different position of the buccal cavity as the observation of the current study and in the herbivorous bottom feeder fish species as in C. mrigala to compensate the restricted visibility in the turbid water in the bottom and in the cavernous fish species the searching on their food particles in the mud as in Tor tor Hamilton, 1822. The third type is observed in a carnivorous fish named C. striata Bloch, 1793 depending on both sight and taste.

The current work described that there was a triangular elevated thickening epithelium named primary tongue as noted in many other teleost fishes, ${ }^{49,50}$ whereas the true tongue had three parts; apex, body and root were described by ${ }^{4}$ in gilthead seabream Sparus aurata, ${ }^{51}$ in pike Esox lucius tongue, ${ }^{52}$ in zebrafish Danio rerio, ${ }^{39}$ in European sea bass Dicentrarchus labrax.

The dorsal lingual surface of the examined fish had numerous lingual tubercles and few numbers of the taste buds. Similarly, the few numbers of the taste buds was recorded by ${ }^{17}$ in Carapus mourlani, but he reported that there were no taste buds in Diretmus species. Furthermore, ${ }^{28,40}$ observed that there were numerous taste buds on the tongue of the Starksiini and the white seabream Diplodus sargus sargus.

Morphologically, there was a median lingual ridge on the dorsal surface as noted in; Clarias gariepinus, ${ }^{53}$ some fish species ${ }^{25}$ and R. rita by, ${ }^{1}$ but $^{36}$ reported the absence of the structure in R. rita tongue. Fantastic observation noted by $^{9,51,54}$ observed that the dorsal lingual surface was characterized by the presence of the papillary-like teeth. Moreover, some fish species 
as lampreys and other parasitic fishes, their tongue containing bony plates that act as teeth-like for rasping and obtaining a blood meal..$^{55}$

The morphological characters of the surface morphology of the oral cavity of different types of fish species were characterized by the presence of the different types of micro ridges which take different names; micro folds, micro ridges, ridges, microvilli, cytoplasmic folds. The current work described these micro ridges in the tongue. The results were confirmed by the descriptions of 1,4,39,54,56-58 in gilthead seabream Sparus aurata $a^{4}$ reported that there were two types of lingual papillae; fungiform and cylindroid papillae, $\mathrm{also}^{40}$ in the white sea bream Diplodus sargus sargus reported that the tongue had mechanical papillae.

The absence of the teeth from the upper jaw with the current results on the lower jaw with its contents (tongue and taste buds), indicated that the lower jaw had an important role in the feeding habits of the examined fish in mudding aquatic condition. ${ }^{59}$

\section{Conclusion}

The two dentaries regions were contained three main structures; the papillary-like teeth that surrounded by a large number of taste buds, in addition to the few number of the large-sized taste pores. The high SEM magnification showed that the papillary-like teeth were surrounded by the circular crypts on its base, and its proximal end was blunted curved and free from epithelium cover. The two dentaries regions were separated from each other by a narrow slightly elevated median region, this region with SEM high magnifications there are numerous filiform-like papillary structures. The dorsal lingual surface contained numerous lingual tubercle and taste buds.

\section{References}

1. Yashpal, M., et al., Surface architecture of the mouth cavity of a carnivorous fish Rita rita (Hamilton, 1822) (Siluriformes, Bagridae). Belg. J. Zool., 2006. 136(2): p. 155-162.

2. Monteiro, S.M., et al., Fine Structure of the Branchial Epithelium in the Teleost Oreochromis niloticus. J. Morphol., 2010. 271: p. 621-633.

3. Abumandour, M.M.A. and M.S. Gewaily, Morphological Studies on the Gills of Puffer Fish (Lagocephalus sceleratus, Gmelin, 1789). Int. J. Morphol., 2016. 34(3): p. 817-829.

4. Abbate, F., et al., Morphology of the tongue dorsal surface of gilthead seabream (Sparus aurata). Microsc Res Tech, 2012. 75(4): p. 1666-1671.

5. Abumandour, M.M.A. and N.E.R. El-Bakary, Gill Morphology in Two Bottom Feeder Mediterranean Sea Fishes: Grey Gurnard Fish (Eutrigla gurnardus, Linnaeus, 1758) and Striped Red Mullet Fish (Mullus barbatus surmuletus, Linnaeus, 1758) by Scanning Electron Microscopy. International Journal of Morphology, 2017. 35(1): p. 77-84.

6. Abumandour, M., Ultrastructure features of the surface of the gills and the lower pharyngeal jaw of the Tilapia Zilli, redbelly tilapia (Coptodon Zillii, Gervais, 1848). Anatomia, histologia, embryologia, 2018.

7. Abumandour, M. and M.S. Gewaily, Morphological Studies on the Gills of Puffer Fish (Lagocephalus sceleratus, Gmelin, 1789). International Journal of Morphology, 2016. 34(3).

8. Roth, G. and D. Wake, Conservatism and innovation in the evolution of feeding in vertebrates. Complex organismal functions: Integration and evolution in vertebrates, 1989: p. 7-21.

9. EL Gendy, S.A., M.A.M. Alsafy, and M. Tanekhy, Morphological Characterization of the Oral Cavity of the Gilthead Seabream (Sparus Aurata) with Emphasis on the Teeth-Age Adaptation. Microsc Res Tech, 2016. in press.

10. Abumandour, M.M.A. and N.E.R. El-Bakary, Morphological features of the tongue and laryngeal entrance in two predatory birds with similar feeding preferences: common kestrel (Falco tinnunculus) and Hume's tawny owl (Strix butleri). Anat Sci Int, 2017. 92(3): p. 352-363.

11.El-Bakary, N. and M. Abumandour, Morphological Studies of the Tongue of the Egyptian Water Buffalo (Bubalus bubalis) and Their Lingual Papillae Adaptation for Its Feeding Habits. Anatomia, Histologia, Embryologia, 2017. 46(5): p. 474-486.

12.Horn, M.H., Feeding and digestion. In: Evans DH, editor. The Physiology of Fishes. Boca Raton: CRC Press. pp 43-63. 1998.

13. Kapoor, B. and B. Khanna, The alimentary canal of teleosts: a brief survey o structure and function. Advances in fish biology, 1994. 1: p. $12-24$.

14. Hansen, A., K. Reutter, and E. Zeiske, Taste bud development in the zebrafish, Danio rerio. Developmental dynamics, 2002. 223(4): p. 483496.

15. Fishelson, L. and Y. Delarea, Taste buds on the lips and mouth of some blenniid and gobiid fishes: comparative distribution and morphology. Journal of Fish Biology, 2004. 65(3): p. 651-665.

16. Atema, J., Structures and functions of the sense of taste in the catfish (Ictalurus natalis). Brain, Behavior and Evolution, 1971. 4(4): p. 273-294. 17. Meyer-Rochow, V., Fish tongues-surface fine structures and ecological considerations. Zoological Journal of the Linnean Society, 1981. 71(4): p. 413-426.

18. Ezeasor, D., Distribution and ultrastructure of taste buds in the oropharyngeal cavity of the rainbow trout, Salmo gairdneri Richardson. Journal of Fish Biology, 1982. 20(1): p. 53-68.

19.Caprio, J., et al., The taste system of the channel catfish: from biophysics to behavior. Trends in neurosciences, 1993. 16(5): p. 192-197. 20. Kapoor, B., H. Smit, and I. Verighina, The alimentary canal and dig estion in teleosts. Advances in marine biology, 1976. 13: p. 109-239.

21. Moyle, P.B. and J.J. Cech, Fishes: An introduction to ichthyology, 3rd edn. Prentice Hall, Upper Saddle River. 1996.

22. Kumari, U., et al., Surface ultrastructure of gill arches and gill rakers in relation to feeding of an Indian major carp, Cirrhinus mrigala. Tissue and Cell, 2009. 41 p. 318-325.

23. Mittal, A. and M. Whitear, A note on cold anaesthesia of poikilotherms. Journal of Fish Biology, 1978. 13(4): p. 519-520.

24. Breipohl, W., G.J. Bijvank, and H.P. Und zippel, Rastermikroskopische untersuchungen der olfaktorischen rezeptoren im riechepithel des goldfisches (Carassius auratus). . Z. Zellforsch., 1973. 138: p. 439-454.

25. Khanna, S.S., A study of the bucco-pharyngeal region in some fishes. $3: 21-48$. Ind. J. Zoot., 1962. 3: p. 21 - 48.

26. Golubtsov, A., K. Moots, and K. Dzerjinskii, Dentition in the African catfishes Andersonia (Amphiliidae) and Siluranodon (Schilbeidae) previously considered toothless. Journal of Fish Biology, 2004. 64(1): p. 146-158.

27. Pasha, S.M.K., The anatomy and histology of the alimentary canal of a carnivorous fishMegalops cyprinoides (Brouss). Proceedings: Plant Sciences, 1964. 60(2): p. 107-115.

28. Fishelson, L., C.C. Baldwin, and P.A. Hastings, Comparison of the oropharyngeal cavity in the Starksiini (Teleostei: Blenniiformes: Labrisomidae): Taste buds and teeth, including a comparison with closely-related genera. Journal of Morphology, 2012. 273(6): p. 618-628. 29.Sire, J. Y., S. Marin, and F. Allizard, Comparison of teeth and dermal denticles (Odontodes) in the teleost Denticeps clupeoides (Clupeomorpha). Journal of Morphology, 1998. 237 p. 237-255.

30. Sire, J.Y. and F. Allizard, A fourth teleosts lineage possessing extraoral teeth : The genus Atherion (teleostei; Atheriniformes). Europ. J. Morph., 2001. 39(1): p. 295 - 305.

31. Fishelson, L., Y. Delarea, and A. Zverdling, Taste bud form and distribution on lips and in the oropharyngeal cavity of cardinal fish 
species (Apogonidae, Teleostei), with remarks on their dentition. J. Morphol., 2004. 259: p. 316-327.

32. Bishop, C. and P. Odense, Morphology of the digestive tract of the cod, Gadus morhua. Journal of the Fisheries Board of Canada, 1966. 23(10): p. 1607-1615.

33. El Bakary, N.E.R., Morphological study of the asymmetrical buccal cavity of the flatfish common solea (Solea solea) and its relation to the type of feeding. Asian Pacific Journal of Tropical Biomedicine, 2014. 4(1): p. 13 - 17.

34. Sastry, K.V., Comparative morphology and histology of the alimentary canal in two teleosts fishes. folia Morphol., 1973. XXI p. 31 $-42$.

35. Saxena, O.P. Relationship of buccopharynx with the food and feeding habits of Labeo dero (Ham.). in Proc. Indian natn. Sci. Acad. 1980.

36. Islam, A.U. The comparative histology of the alimentary canal of certain freshwater teleost fishes. in Proc. Ind. Acad. Sci. 1951.

37. Levanti, M., et al., The Tongue Dorsal Surface in Fish: A Comparison Among Three Farmed Species. Anatomia, Histologia, Embryologia, 2016. 38. Reutter, K., Taste organ in the bullhead (Teleostei). Advances in anatomy, embryology, and cell biology, 1978. 55(1): p. 3.

39. Abbate, F., et al., Morphology of the European sea bass (Dicentrarchus labrax) tongue. Microscopy Research and Technique, 2012. 75(5): p. 643-649.

40. Guerrera, M.C., et al., Morphology of the tongue dorsal surface in white sea bream (Diplodus sargus sargus). Acta Zoologica, 2015. 96(2): p. 236-241.

41. Tripathi, P. and A.K. Mittal, Essence of keratin in lips and associated structures of a freshwater fish Puntius sophore in relation to its feeding ecology: Histochemistry and scanning electron microscope investigation. Tissue and Cell, 2010. 42(4): p. 223-233.

42. Tripathi, P. and A.K. Mittal, Diversity of Lips and Associated Structures in Fishes by SEM. 2012: INTECH Open Access Publisher.

43. Shallenberger, R., T. Acree, and L. Beidler, Handbook of Sensory Physiology. IV; Chemical Senses, 2. Taste. 1971, Springer-Verlag Berlin.

44. Hara, T.J., Olfaction and gustation in fish : an overview. Acta Physiol. Scand., 1994. 152 p. 207-217.

45. Fishelson, L., et al., Comparative morphology of the eye (with particular attention to the retina) in various species of cardinal fish (Apogonidae, Teleostei). The Anatomical Record Part A: Discoveries in Molecular, Cellular, and Evolutionary Biology, 2004. 277(2): p. 249-261. 46. Yashpal, M., et al., Morphological specializations of the buccal cavity in relation to the food and feeding habit of a carp Cirrhinus mrigala: A scanning electron microscopic investigation. Journal of Morphology, 2009. 270(6): p. 714-728.

47. Whitear, M. and R.M. Moate, Microanatomy of taste buds in the dogfish. Scyliorbinus canicula. J Submicrosc Cytol Pathol, 1994(552): p. 357-367.

48. Khanna, S., The structure and distribution of the taste buds and the mucus secreting cells in the buccopharynx of some Indian teleosts (Pisces). Studies DSB Govt College Nanital India, 1968. 5: p. 143-148. 49. Genten, F., E. Terwinghe, and A. Danguy, Atlas of Fish Histology. 2009: Science Publishers.

50. Buddington, R.K. and V. Kuz'mina, Digestive system., in The Laboratory Fish, G.K. Ostrander, Editor. 2000, Baltimore, MD: Academic Press.

51. Sadeghinezhad, J., et al., Morphological study of the northern pike (Esox lucius) tongue. anatomical science international, 2015. 90: p. 235-239.

52. Abbate, F., et al., The oral cavity of the adult zebrafish (Danio rerio). Anatomia, Histologia, Embryologia, 2006. 35(5): p. 299-304.

53. Gamal, A., E. Elsheikh, and E. Nasr, Morphological adaptation of the buccal cavity in relation to feeding habits of the omnivorous fish Clarias gariepinus: A scanning electron microscopic study. The Journal of Basic \& Applied Zoology, 2012. 65(3): p. 191-198.

54. El-Bakary, N.E.R., Comparative Scanning Electron Microscope Study of the Buccal Cavity in Juvenile and Adult Sea Bass (Dicentrachus labrax). World Applied Sciences Journal, 2011. 12(8): p. 1133-1138.

55. Bond, C.E., Feeding and nutrition. In: Biology of fishes. Saunders college publishing. pp: 391-405. 1979.

56. Whitear, M., Causative aspects of microridges on the surface of fish epithelia. J. Submicrosc. Cytol. Pathol., 1990. 22: p. 211 - 220.

57. Olson, K.R., Scanning electron microscopy of fish gill. In: Datta Munshi, J.S., Dutta, H.M. (Eds.), Fish Morphology: Horizon of New Research. Oxford and IBH publishing Co. Pvt. Ltd., New Delhi, pp. 31-45. 1995.

58. Mittal, S., Pinky, and A.K. Mittal, Operculum of peppered loach, Lepidocephalichthys guntea (Hamilton, 1822)(Cobitidae, Cypriniformes): a scanning electron microscopic and histochemical investigation. Belg. J. Zool., 2004. 134: p. 9 - 15.

59. Lo Bianco, S., L'origine dei barbigli tattili nel genere Mullus. Atti della Reale Accademia dei Lincei. Rendiconti della Classe di Scienze fisiche, matematiche e naturali, 1907. 16: p. 577-586.
Received: June 2, 2019

Accepted: Octuber 22, 2019
Corresponding author

Mohamed M.A. Abumandour

E-mail:m.abumandour@yahoo.com 